\title{
Neural Crest
}

National Cancer Institute

\section{Source}

National Cancer Institute. Neural Crest. NCI Thesaurus. Code C34222.

A cell region originating at the margins of the dorsal part of the neural tube during the early stages of embryonic development that migrates to multiple locations within the embryo, and are multipotent, giving rise to a vast number of differentiated cell and tissue types. 